Original Research Paper

\title{
Traditional Medicinal Plants Used by the Community of Sri Wangi Village, Kapuas Hulu Regency
}

\author{
Fathul Yusro $^{1 *} \&$ Yeni Mariani ${ }^{1}$ \\ ${ }^{1}$ Forestry Faculty, Tanjungpura University, Pontianak, Indonesia
}

\author{
Article History \\ Received : October $06^{\text {th }}, 2021$ \\ Revised : October $18^{\text {th }}, 2021$ \\ Accepted : October 29 $9^{\text {th }}, 2021$ \\ Published : November $06^{\text {th }}, 2021$ \\ *Corresponding Author: \\ Fathul Yusro, \\ Forestry Faculty, Tanjungpura \\ University, Pontianak \\ Email: fathulyusro@gmail.com
}

\begin{abstract}
Kapuas Hulu Regency is a Conservation District because most of the area is protected forest (National Parks and Protected Forests). The existence of people who are close to the forest makes them often interact with plants, one of which is with medicinal plants. This study aimed to analyze the species of medicinal plants used by the community of Sri Wangi Village, Boyan Tanjung District, Kapuas Hulu Regency. This study used snowball sampling method for collect the data. The data collected were species of medicinal plants, the medicinal plants' efficacy, the parts used, processing and administration methods. The results showed a total of 34 medicinal species (19 famlies) used by the community. The highest use of plant part are leaves $(30 \%)$, while for processing and administration method are boiled $(43.59 \%)$, and drunk $(43.59 \%)$. The data on the species of medicinal plants used by the people of Sri Wangi Village can add to the repertoire of knowledge of medicinal plants in West Kalimantan.
\end{abstract}

Keywords: Medicinal plants, Sri Wangi village, traditional knowledge

\section{Pendahuluan}

Kapuas Hulu merupakan kabupaten di Kalimantan Barat yang ditetapkan sebagai Kabupaten Konservasi (Perda Kapuas Hulu No. 21, 2015). Hal ini dikarenakan sebagian besar wilayahnya masuk dalam Kawasan Hutan yang dilindungi (Taman Nasional dan Hutan Lindung) (Perda Kapuas Hulu No. 21, 2015). Keberadaan masyarakat di kabupaten ini yang dekat dengan hutan menjadikan mereka sering berinteraksi dengan tumbuhan, baik tumbuhan yang masih berada dihutan ataupun tumbuhan yang sudah dibudidayakan oleh mereka disekitar rumah. Salah satu bentuk interaksi mereka dengan tumbuhan adalah pemanfaatannya sebagai bahan obat tradisional.

Kajian mengenai penggunaan tumbuhan obat oleh masyarakat pada beberapa wilayah di Kabupaten Kapuas Hulu telah dilakukan seperti pada masyarakat sekitar Kawasan KPH Model (Haryanti et al., 2015), di Dusun Sungai Tekuyung khususnya pada suku Dayak Suru' (Joni et al., 2015), Desa Sungai Mawang khususnya pada suku Dayak Iban (Pradityo et al.,
2016), Desa Sepandan dan Lanjak Besar khususnya pada suku Dayak Iban (Yusro et al., 2019), Desa Laban Ira'ang (Tuah et al., 2019) dan Desa Seluan khususnya pada suku Dayak Kantuk (Liliyanti et al., 2021). Masih banyak wilayah-wilayah lain di kabupaten Kapuas Hulu yang belum dilaporkan terkait dengan pemanfaatan tumbuhan obat oleh masyarakatnya, salah satunya adalah di Desa Sri Wangi Kecamatan Boyan Tanjung.

Desa Sri Wangi sebagian wilayahnya masuk dalam Kawasan Hutan dan di desa ini juga terdapat hutan yang di kelola oleh masyarakat setempat yaitu Hutan Desa Nyuai Peningun. Adanya hutan disekitar rumah mereka menjadikan hutan tersebut sebagai salah satu sumber penghidupan bagi masyarakat terutama hasil hutan bukan kayunya (HHBK). Salah satu produk hhbk tersebut adalah tumbuhan obat. Namun hingga saat ini belum diketahui jenisjenis tumbuhan obat apa saja yang telah dimanfaatkan oleh masyarakat Desa Sri Wangi, apa saja khasiat tumbuhan obat tersebut, bagian apa dari tanaman tersebut yang digunakan dalam pengobatan, dan bagaimana pula cara 
pengolahan dan penggunaan tumbuhan obat tersebut. Penelitian ini bertujuan untuk menganalisis jenis-jenis tumbuhan obat yang dimanfaatkan oleh masyarakat Desa Sri Wangi Kecamatan Boyan Tanjung Kabupaten Kapuas Hulu.

\section{Bahan dan Metode}

\section{Waktu dan Tempat Penelitian}

Desa Sri Wangi Kecamatan Boyan Tanjung Kabupaten Kapuas Hulu merupakan tempat dilaksanakannya penelitian ini (Gambar 1). Adapun waktu pelaksanaan penelitian pada bulan Juni 2021.

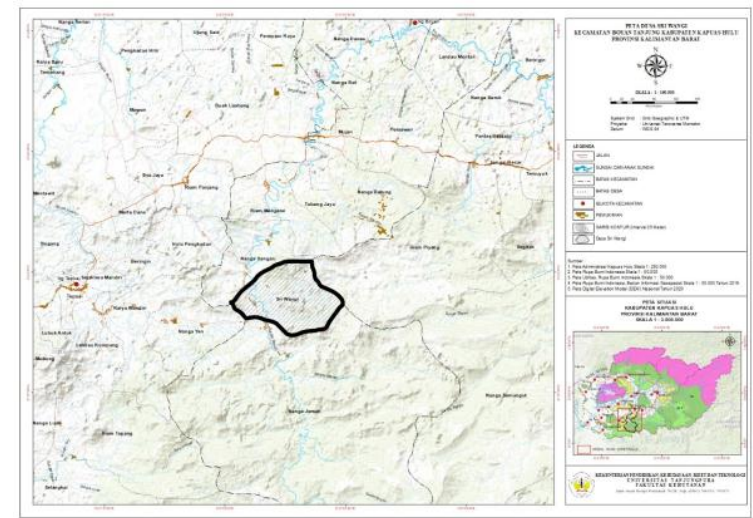

Gambar 1. Tempat dilaksanakannya penelitian (Desa Sri Wangi Kecamatan Boyan Tanjung Kabupaten Kapuas Hulu)

\section{Alat dan Objek Penelitian}

Penelitian ini menggunakan beberapa peralatan seperti panduan wawancara (daftar pertanyaan), kamera, perekam suara dan buku jenis tumbuhan obat tradisional Kalimantan Barat untuk memudahkan dalam kegiatan identifikasi tanaman (Yusro et al., 2020).

Objek penelitian ini adalah keseluruhan jenis-jenis tumbuhan obat yang dimanfaatkan sebagai bahan obat tradisional oleh masyarakat Desa Sri Wangi Kecamatan Boyan Tanjung Kabupaten Kapuas Hulu.

\section{Pengumpulan Data}

Penelitian ini dilakukan dengan metode survey. Adapun pengumpulan data dengan cara snowball sampling. Responden penelitian ini adalah masyarakat setempat yang mengetahui dan memanfaatkan tumbuhan obat. Data yang dikumpulkan adalah jenis-jenis tumbuhan obat yang dimanfaatkan oleh masyarakat, khasiat apa saja dari tumbuhan obat yang digunakan, bagian tanaman yang digunakan, bagaimana cara pengolahan maupun penggunaan tumbuhan obat tersebut.

\section{Analisis Data}

Data jenis tumbuhan, bagian tanaman yang dimanfaatkan, cara pengolahan dan penggunaannya selanjutnya dianalisis dalam bentuk tabel dan grafik.

\section{Hasil dan pembahasan}

\section{Jenis-jenis Tumbuhan Berkhasiat Obat}

Tumbuhan obat oleh masyarakat Desa Sri Wangi masih terus dimanfaatkan untuk pengobatan tradisional, dan banyak diantara tumbuhan obat tersebut telah dibudidayakan disekitar rumah agar memudahkan dalam pengambilan jika suatu saat dibutuhkan. Jumlah tanaman obat yang dimanfaatkan oleh masyarakat sebanyak 34 jenis dan terdistribusi pada 19 famili (Tabel 1). Jenis-jenis tanaman ini lebih banyak jika dibandingkan dengan wilayah lain di Kabupaten Kapuas Hulu seperti di Desa Sepandan dan Lanjak Besar khususnya yang dimanfaatkan suku Dayak Iban untuk mengatasi gangguan pencernaan dengan jumlah tanaman sebanyak 21 jenis (Yusro et al., 2019), Dusun Sungai Tengkuyung khususnya yang dimanfaatkan suku Dayak Suru' sebanyak 24 jenis (Joni et al., 2015), dan Desa Seluan khususnya yang dimanfaatkan suku Dayak Kantuk untuk mengatasi masalah pada rambut sebanyak 15 jenis (Liliyanti et al., 2021).

Beberapa jenis tanaman yang digunakan diambil dari hutan seperti belian (Eusideroxylon zwageri), bajakah (Spatholobus littoralis), kandis (Garcinia xanthochymus) dan pasak bumi (Eurycoma longifolia). Tanaman belian (Eusideroxylon zwageri) secara tradisional digunakan oleh masyarakat untuk mempercepat anak berjalan. Tanaman ini diketahui mengandung alkaloid, flavonoid, fenolik, saponin, terpenoid, tanin dan memiliki aktivitas sebagai antibakteri (Wila et al., 2018; Mariani et al., 2020) dan anti inflamasi (Mariani et al., 2016). 
Yusro \& Mariani (2021). Jurnal Biologi Tropis, 21 (3): 1030 - 1037

DOI: http://dx.doi.org/10.29303/jbt.v21i3.3007

Tabel 1. Jenis-jenis tumbuhan obat yang digunakan oleh masyarakat Desa Sri Wangi Kecamatan Boyan Tanjung Kabupaten Kapuas Hulu

\begin{tabular}{|c|c|c|c|c|c|c|c|}
\hline No. & Nama lokal & Nama latin & Famili & Khasiat & $\begin{array}{l}\text { Bagian } \\
\text { tanaman }\end{array}$ & $\begin{array}{l}\text { Cara } \\
\text { pengolahan }\end{array}$ & $\begin{array}{l}\text { Cara } \\
\text { penggunaan }\end{array}$ \\
\hline 1 & $\begin{array}{l}\text { Akar kuning } \\
\text { daun besar, } \\
\text { temu tegak }\end{array}$ & Arcangelisia flava & Menispermaceae & $\begin{array}{l}\text { Meningkatkan daya tahan } \\
\text { tubuh, meningkatkan stamina }\end{array}$ & Akar & Rebus & Minum \\
\hline 2 & $\begin{array}{l}\text { Akar kuning } \\
\text { daun kecil }\end{array}$ & Fibraurea tincturia & Menispermaceae & $\begin{array}{l}\text { Meningkatkan daya tahan } \\
\text { tubuh }\end{array}$ & Akar & Rebus & Minum \\
\hline 3 & Akar mulang & - & - & Memulihkan stamina & $\begin{array}{l}\text { Akar (air } \\
\text { yang keluar) }\end{array}$ & $\begin{array}{l}\text { Tanpa } \\
\text { pengolahan }\end{array}$ & Minum \\
\hline 4 & Akar temedak & - & - & Sakit perut & $\begin{array}{l}\text { Akar (air } \\
\text { yang keluar) }\end{array}$ & $\begin{array}{l}\text { Tanpa } \\
\text { pengolahan }\end{array}$ & Minum \\
\hline 5 & Bajakah & Spatholobus littoralis & Fabaceae & Memulihkan stamina, kanker & Akar & Rebus & Minum \\
\hline 6 & Bambu kuning & $\begin{array}{l}\text { Bambusa vulgaris var. } \\
\text { striata }\end{array}$ & Poaceae & Demam, pusing & Batang & Rebus & Minum \\
\hline 7 & $\begin{array}{l}\text { Bawang } \\
\text { lembak }\end{array}$ & Eleutherine bulbosa & Iridaceae & Demam & Umbi & Tumbuk & Tempel \\
\hline 8 & Beleban & Vitex $s p$ & Lamiaceae & Penyakit kulit & Kulit kayu & Rebus & Mandi \\
\hline 9 & Belian & Eusideroxylon zwageri & Lauraceae & Mempercepat anak berjalan & Daun & Tumbuk & Oles \\
\hline 10 & Damar agatis & Agathis sp & Araucariaceae & Luka pasca sunat & Damar & Kikis halus & Oles \\
\hline 11 & Engkerbang & Psychotria viridiflora & Rubiaceae & Penyakit kulit & Daun & Rebus & Mandi \\
\hline 12 & Ginseng & Panax $s p$ & Araliaceae & Meningkatkan stamina & Akar & Rebus & Minum \\
\hline 13 & Jambu biji & Psidium guajava & Myrtaceae & Sakit perut & Daun & Rebus & Minum \\
\hline 14 & Kabu & Ceiba pentandra & Malvaceae & $\begin{array}{l}\text { Demam pada anak, sakit } \\
\text { kepala }\end{array}$ & Daun & Rebus, remas & Minum \\
\hline 15 & Kandis & Garcinia xanthochymus & Cluciaceae & $\begin{array}{l}\text { Luka pasca sunat, } \\
\text { membersihkan darah pasca } \\
\text { bersalin, bengkak }\end{array}$ & Getah, buah & $\begin{array}{l}\text { Tanpa } \\
\text { pengolahan, } \\
\text { tumbuk }\end{array}$ & Oles, minum \\
\hline 16 & Kemunting & $\begin{array}{l}\text { Melastoma } \\
\text { malabraticum }\end{array}$ & Melastomataceae & Luka & Daun & Kunyah & Oles \\
\hline 17 & Ketepeng & Cassia alata & Fabaceae & Penyakit kulit & Daun & Bakar & Oles \\
\hline 18 & Kopi & Coffea sp & Rubiaceae & Sakit perut & Daun & Rebus & Minum \\
\hline 19 & Kunyit & Curcuma longa & Zingiberaceae & $\begin{array}{l}\text { Meningkatkan daya tahan } \\
\text { tubuh, memulihkan stamina, } \\
\text { bengkak, sakit kepala }\end{array}$ & Rimpang & Rebus, tumbuk & $\begin{array}{l}\text { Minum, oles, } \\
\text { tempel }\end{array}$ \\
\hline 20 & Leban & Vitex pubescens & Lamiaceae & Maag, cacar & $\begin{array}{l}\text { Kulit kayu, } \\
\text { buah }\end{array}$ & Rebus & Oles, minum \\
\hline
\end{tabular}


Yusro \& Mariani (2021). Jurnal Biologi Tropis, 21 (3): 1030 - 1037 DOI: http://dx.doi.org/10.29303/jbt.v21i3.3007

\begin{tabular}{|c|c|c|c|c|c|c|c|}
\hline No. & Nama lokal & Nama latin & Famili & Khasiat & $\begin{array}{l}\text { Bagian } \\
\text { tanaman }\end{array}$ & $\begin{array}{l}\text { Cara } \\
\text { pengolahan }\end{array}$ & $\begin{array}{l}\text { Cara } \\
\text { penggunaan }\end{array}$ \\
\hline 21 & Lengkuas & Alpinia galanga & Zingiberaceae & Panu & Rimpang & Tumbuk & Gosok \\
\hline 22 & Letup & Passiflora foetida & Passifloraceae & $\begin{array}{l}\text { Demam, tipes, diabetes, } \\
\text { liver, batuk, TBC }\end{array}$ & $\begin{array}{l}\text { Semua bagian } \\
\text { tanaman, akar }\end{array}$ & Rebus & Minum \\
\hline 23 & Mengelai & Curcuma sp & Zingiberaceae & Nyeri tulang & Rimpang & Tumbuk & Tempel \\
\hline 24 & Pasak bumi & Eurycoma longifolia & Simaroubaceae & $\begin{array}{l}\text { Liver, demam, stamina, } \\
\text { rematik, pegal linu }\end{array}$ & Akar, batang & Rebus & Minum \\
\hline 25 & Pulai, pelae & Alstonia scholaris & Apocynaceae & $\begin{array}{l}\text { Demam, malaria, sakit gigi, } \\
\text { luka }\end{array}$ & Getah, batang & $\begin{array}{l}\text { Tanpa } \\
\text { pengolahan, } \\
\text { rebus }\end{array}$ & Tetes, minum \\
\hline 26 & Puri & Mitragyna speciosa & Rubiaceae & Menambah stamina & Daun & Rebus & Minum \\
\hline 27 & $\begin{array}{l}\text { Rumput nyabu } \\
\text { sawa, rumput } \\
\text { serawak, } \\
\text { rumput laut }\end{array}$ & Axonopus fissifolius & Poaceae & Luka & Daun & $\begin{array}{l}\text { Kunyah, } \\
\text { tumbuk }\end{array}$ & Tempel \\
\hline 28 & Sengkubak & Pycharrhena cauliflora & Menispermaceae & Keracunan & Buah & $\begin{array}{l}\text { Tanpa } \\
\text { pengolahan }\end{array}$ & Makan \\
\hline 29 & Serai & Cymbopogon citratus & Poaceae & Pegal-pegal & Batang & Tumbuk & Gosok \\
\hline 30 & Serai wangi & Cymbopogon nardus & Poaceae & Pegal-pegal & Daun & Suling & Gosok \\
\hline 31 & Sinduk & - & - & $\begin{array}{l}\text { Menghangatkan badan, beri- } \\
\text { beri, demam }\end{array}$ & Daun & Rebus & Makan \\
\hline 32 & $\begin{array}{l}\text { Tarum buaya, } \\
\text { cangkok hutan }\end{array}$ & Sauropus sp & Phyllanthaceae & Luka, infeksi kuku & Daun, buah & Tumbuk & Oles \\
\hline 33 & Terong pipit & Solanum torvum & Solanaceae & Sakit gigi & Buah & Bakar & Oles \\
\hline 34 & Tiangcit & Kaempferia parviflora & Zingiberaceae & Bengkak, demam & Rimpang & Tumbuk & Tempel \\
\hline
\end{tabular}


Bajakah (Spatholobus littoralis) secara tradisional digunakan oleh masyarakat untuk memulihkan stamina dan mengobati kanker. Tanaman ini diketahui mengandung beberapa komponen bioaktif seperti fenolik, flavonoid, tanin, saponin dan memiliki aktivitas dalam mempersingkat waktu penyembuhan luka (Saputera \& Ayuchecaria, 2018) dan sebagai antibakteri (Saputera et al., 2019).

Kandis (Garcinia xanthochymus) secara tradisional digunakan oleh masyarakat untuk penyembuhan luka pasca sunat, membersihkan darah pasca bersalin, dan bengkak. Beberapa senyawa yang terkandung dalam tanaman ini antara lain xanthon, flavonoid, fenolik dan memiliki aktivitas sebagai anti inflamasi (Hamidon et al., 2016) dan senyawa garciniaxanthone mengarah pada pemanfaatannya dalam pengobatan kanker liver (Jin et al., 2019).

Pasak bumi (Eurycoma longifolia) secara tradisional digunakan oleh masyarakat untuk mengobati penyakit liver, demam, stamina, rematik, dan pegal linu. Senyawa yang terkandung dalam tanaman ini antara lain eurylophenolosida dan eurylolignanosida (Ruan et al., 2019), dan memiliki aktivitas sebagai anti malaria, anti proliferatif, anti mikroba, anti inflamasi, antidiabetes, dan pencegahan osteoporosis (Rehman et al., 2016).

\section{Bagian Tanaman}

Beberapa bagian tanaman yang digunakan dalam pengobatan tradisional oleh masyarakat Desa Sri Wangi antara lain akar, daun, buah, batang, rimpang, getah, semua bagian, kulit kayu, damar dan umbi. Bagian tanaman dengan penggunaan tertinggi adalah daun (30\%) (Gambar 2). Beberapa jenis tanaman dengan daun sebagai bahan utama dalam pengobatan antara lain belian, engkerbang, jambu biji, kabu, kemunting, ketepeng, kopi, puri, rumput nyabu sawa, serai wangi, sinduk dan tarum buaya.

Banyak laporan menunjukkan bahwa masyarakat di Kalimantan Barat menggunakan daun sebagai bahan utama dalam pengobatan tradisional seperti di Desa Sepandan dan Lanjak Besar Kabupaten Kapuas Hulu (Yusro et al., 2019), Desa Rantau Panjang Kabupaten Kayong Utara (Saupi et al., 2021) dan Desa Tonang Kabupaten Landak (Sari et al., 2021). Banyak faktor yang diduga menyebabkan tingginya penggunaan daun dalam pengobatan seperti karena kandungan metabolit sekunder yang terkandung didalamnya (Ardiana et al., 2019), proses untuk mengolah dan meramunya cukup mudah (Yusro et al., 2019) dan tidak terlalu merusak tanaman jika digunakan secara terus menerus (Ardiana et al., 2019).

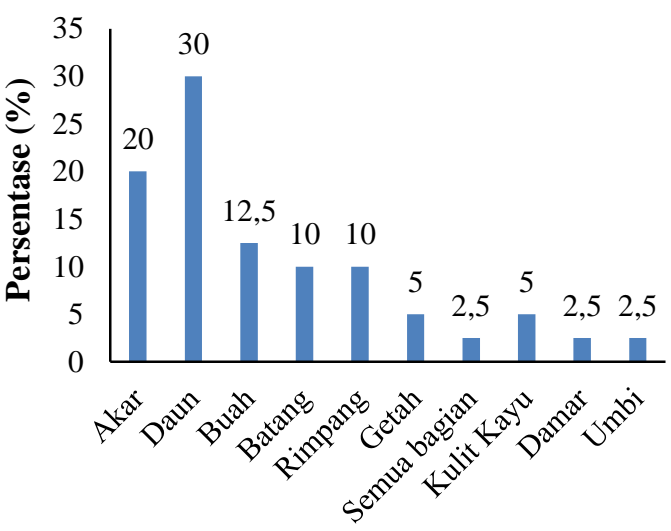

Bagian tanaman

Gambar 2. Bagian tanaman yang dimanfaatkan sebagai bahan obat oleh masyarakat Desa Sri Wangi

\section{Cara Pengolahan Tanaman Obat}

Masyarakat Desa Sri Wangi mengolah tumbuhan obat dengan beragam cara seperti direbus, tumbuk, bakar, kunyah, remas, kikis, suling dan tanpa pengolahan. Perebusan merupakan cara pengolahan tertinggi yaitu sebesar 43,59\% (Gambar 3).

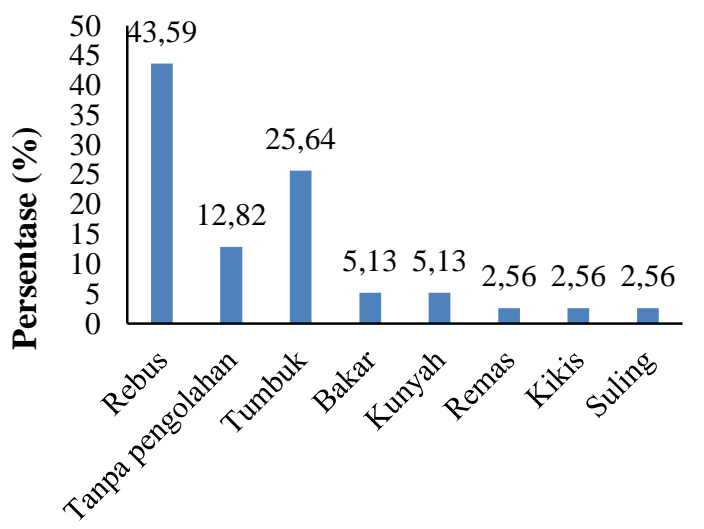

\section{Cara pengolahan}

Gambar 3. Cara pengolahan tanaman obat oleh masyarakat Desa Sri Wangi

Perebusan sebagai cara dalam mengolah tumbuhan obat juga banyak dilaporkan di 
wilayah lain di Kalimantan Barat seperti di Desa Laban Ira'ang Kabupaten Kapuas Hulu (Tuah et al., 2019), Desa Tonang Kabupaten Landak (Sari et al., 2021), Desa Rantau Panjang Kabupaten Kayong Utara (Saupi et al., 2021) dan Desa Kuala Dua Kabupaten Sanggau (Yusro et al., 2021). Pengolahan dengan cara perebusan diduga mempercepat proses keluarnya zat ektraktif yang terkandung dalam tanaman (Tugume et al., 2016) dan aroma mentah dari tanaman dapat dihilangkan sehingga memudahkan dalam mengkonsumsinya (Jani et al., 2019).

\section{Cara Penggunaan Tanaman Obat}

Masyarakat Desa Sri Wangi memiliki beragam cara dalam menggunakan tumbuhan obat antara lain dengan diminum, dimakan, dioles, digosok, ditempel, dimandikan dan ditetes. Meminum ramuan merupakan cara penggunaan tertinggi $(43,59 \%)$ (Gambar 4).

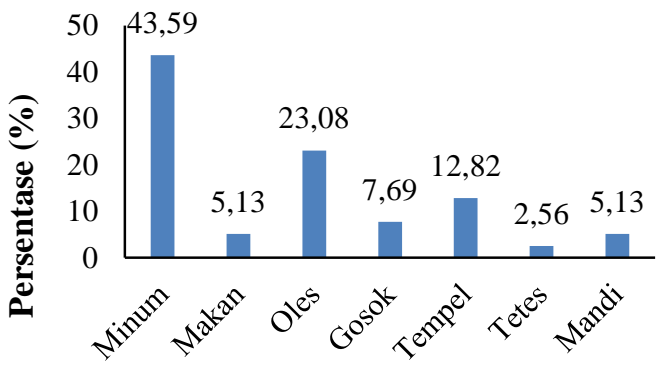

Cara menggunakan

Gambar 4. Cara menggunakan tanaman obat oleh masyarakat Desa Sri Wangi

Beberapa wilayah lain di Kalimantan Barat juga banyak yang menggunakan tumbuhan obat dengan cara diminum seperti di Desa Laban Ira'ang Kabupaten Kapuas Hulu (Tuah et al., 2019), Desa Kuala Dua Kabupaten Sanggau (Yusro et al., 2021), Desa Tonang Kabupaten Landak (Sari et al., 2021), dan Desa Rantau Panjang Kabupaten Kayong Utara (Saupi et al., 2021). Banyaknya penggunaan tumbuhan obat dengan cara diminum diduga karena terkait dengan efektifitasnya yang lebih tinggi dibandingkan dengan cara yang lain (Tugume et $a l ., 2016)$, meskipun hal ini sangat bergantung pada jenis penyakit yang dialami oleh masyarakat.

\section{Kesimpulan}

Tumbuhan obat oleh masyarakat Desa Sri Wangi masih digunakan dan hingga saat ini tercatat sebanyak 34 jenis digunakan untuk beragam kategori penyakit. Beberapa jenis tanaman masih diambil dari hutan seperti belian (Eusideroxylon zwageri), bajakah (Spatholobus littoralis), kandis (Garcinia xanthochymus) dan pasak bumi (Eurycoma longifolia). Penggunaan tumbuhan obat secara tradisional tersebut perlu untuk dilestarikan dan kedepannnya perlu untuk dibuktikan secara ilmiah mengenai khasiat dan kandungan senyawa bioaktif yang dimiliki oleh setiap tanaman obat.

\section{Ucapan Terima Kasih}

Terima kasih diucapkan kepada PRCFI yang telah mendanai kegiatan penelitian ini, tokoh adat, Kepala Desa beserta jajarannya serta seluruh masyarakat yang telah membantu kegiatan penelitian ini.

\section{Referensi}

Ardiana, N., Mariani, Y., \& Tavita, G. E. (2019). Studi Pemanfaatan Tumbuhan Obat Berpotensi Sebagai Anti-Inflamasi Di Desa Teluk Batang Utara Kecamatan Teluk Batang Kabupaten Kayong Utara. Jurnal Hutan Lestari, 7(3), 1111-1129. https://doi.org/10.26418/jhl.v7i3.37266

Hamidon, H., Taher, M., Jaffri, J. M., Tg Zakaria, T. M., Sulaiman, W. M., Susanti, D., Ichwan, S. J., \& Zakaria, Z. A. (2016). Cytotoxic and Anti-Inflammatory Activities of Garcinia xanthochymus Extracts on Cell Lines. Makara Journal of Health Research, 20(1), 11-17. https://doi.org/10.7454/msk.v20i1.5599

Haryanti, E. S., Diba, F., \& Wahdina. (2015). Etnobotani Tumbuhan Berguna oleh Masyarakat Sekitar Kawasan KPH Model Kapuas Hulu. Jurnal Hutan Lestari, 3(3), 434-445. https://doi.org/dx.doi.org/10.26418/jhl.v3i 3.11370

Jani, K. A., Nono, K. M., \& Amalo, D. (2019). Inventarisasi Tumbuhan Obat Tradisional di Masyarakat Etnis Kempo, Desa Cunca Lolos, Kecamatan Mbeliling, Kabupaten 
Manggarai Barat, NTT. Jurnal Biotropikal Sains, 16(1), 73-79. https://ejurnal.undana.ac.id/index.php/biotr opikal/issue/view/158

Jin, S., Shi, K., Liu, L., Chen, Y., \& Yang, G. (2019). Xanthones from the Bark of Garcinia xanthochymus and the Mechanism of Induced Apoptosis in Human Hepatocellular Carcinoma HepG2 Cells Via the Mitochondrial Pathway. International Journal of Molecular Sciences, 20(19). https://doi.org/10.3390/ijms20194803

Joni, A., Oramahi, H. A., \& Ardian, H. (2015). Etnobotani Masyarakat Dayak Suru' Studi Kasus Dusun Sungai Tekuyung Desa Tangai Jaya Kecamatan Mentebah Kabupaten Kapuas Hulu. Jurnal Hutan Lestari, 3(4), 617-624. https://doi.org/10.26418/jhl.v3i4.13925

Liliyanti, M., Mariani, Y., \& Yusro, F. (2021). Pemanfaatan Tumbuhan Obat untuk Perawatan Rambut oleh Suku Dayak Kantuk di Desa Seluan Kabupaten Kapuas Hulu Kalimantan Barat. Bioma: Jurnal Ilmiah Biologi, 10(2), 228-247. https://doi.org/10.26877/bioma.v10i2.9019

Mariani, Y, Yusro, F., Konishi, Y., Taguchi, T., \& Tominaga, A. (2016). Regulatory Effects of Five Medicinal Plants Used by Dayak Uud Danum in West Kalimantan Indonesia on the Delayed-Type Hypersensitivity and the Inflammation of Human Colon Epithelial Cells. Kuroshio Science, 10(1), 59-71. http://www.kochiu.ac.jp/kuroshio/f01 a-kuroshio-sciencee.html

Mariani, Yeni, Yusro, F., \& Wardenaar, E. (2020). Aktivitas Ekstrak Metanol Daun Ulin (Eusideroxylon Zwageri Teijsm \& Binn) Terhadap Empat Jenis Bakteri Patogen. Jurnal Biologi Tropis, 20(1), 94. https://doi.org/10.29303/jbt.v20i1.1642

Perda Kapuas Hulu No. 21. (2015). Peraturan Daerah Kabupaten Kapuas Hulu Nomor 21 Tahun 2015 Tentang Penetapan Kabupaten Kapuas Hulu Sebagai Kabupaten Konservasi.

Rehman, S. U., Choe, K., \& Yoo, H. H. (2016). Review on a Traditional Herbal Medicine, Eurycoma longifolia Jack (Tongkat Ali): Its Traditional Uses, Chemistry, Evidence-
Based Pharmacology and Toxicology. Molecules, 21(3). https://doi.org/10.3390/molecules2103033 1

Ruan, J., Li, Z., Zhang, Y., Chen, Y., Liu, M., Han, L., Zhang, Y., \& Wang, T. (2019). Bioactive Constituents from the Roots of Eurycoma longifolia. Molecules, 24(17), 116.

https://doi.org/10.3390/molecules2417315 7

Saputera, M. M. A., \& Ayuchecaria, N. (2018). Uji Efektivitas Ekstrak Etanolik Batang Bajakah (Spatholobus littoralis Hassk.) Terhadap Waktu Penyembuhan Luka. Jurnal Ilmiah Ibnu Sina, 3(2), 318-327. https://doi.org/10.36387/jiis.v3i2.185

Saputera, M. M. A., Marpaung, T. W. A., \& Ayuchecaria, N. (2019). Konsentrasi Hambat Minimum (KHM) Kadar Ekstrak Etanol Batang Bajakah Tampala (Spatholobus littoralis Hassk) Terhadap Bakteri Escherichia coli Melalui Metode Sumuran. Jurnal Ilmiah Manuntung, 5(2), 167-173. https://doi.org/10.51352/jim.v5i2.267

Sari, R. P., Yusro, F., \& Mariani, Y. (2021). Medicinal Plants Used by Dayak Kanayatn Traditional Healers in Tonang Village Sengah Temila District Landak Regency. Jurnal Biologi Tropis, 21(2), 324. https://doi.org/10.29303/jbt.v21i2.2557

Saupi, M., Yanti, H., Mariani, Y., \& Yusro, F. (2021). Local Wisdom of the Rantau Panjang Community, Simpang Hilir District, Kayong Utara Regency in Utilizing Medicinal Plants. Jurnal Biologi Tropis, 21(3), 805-817. https://doi.org/10.29303/jbt.v21i3.2949

Tuah, I., Dirhamsyah, M., \& Tavita, G. E. (2019). Kajian Pemanfaatan Tumbuhan Obat oleh Masyarakat Desa Laban Ira'ang Kecamatan Batang Lupar Kabupaten Kapuas Hulu. Jurnal Hutan Lestari, 7(3), 983-991. https://doi.org/10.26418/jhl.v7i3.35159

Tugume, P., Kakudidi, E. K., Buyinza, M., Namaalwa, J., Kamatenesi, M., Mucunguzi, P., \& Kalema, J. (2016). Ethnobotanical Survey of Medicinal Plant Species Used by Communities Around Mabira Central Forest Reserve, Uganda. Journal of Ethnobiology and 
Ethnomedicine, 12(1), 1-28. https://doi.org/10.1186/s13002-015-00774

Wila, H., Yusro, F., \& Mariani, Y. (2018). Skrining Fitokimia dan Aktivitas Antibakteri Ekstrak Kulit Batang (Eusideroxylon zwageri) Terhadap Escherichia coli dan Salmonella typhi. Jurnal Tengkawang, 8(1), 38-49. https://doi.org/10.26418/jt.v8i1.30147

Yusro, F., Mariani, Y., \& Wardenaar, E. (2019). Pemanfaatan Tumbuhan Obat untuk Mengatasi Gangguan Sistem Pencernaan oleh Suku Dayak Iban: Studi Kasus di Kabupaten Kapuas Hulu Kalimantan Barat. Jurnal Borneo Akcaya, 5(1), 58-72. http://jurnal- litbang.kalbarprov.go.id/index.php/litbang/ article/view/120

Yusro, F., Mariani, Y., \& Wardenaar, E. (2021). The Utilization of Medicinal Plants to Overcome Gastric Disorders by The Dayak Muara Tribe in Kuala Dua Village, Sanggau Regency. Jurnal Biologi Tropis, 21(2), 416. https://doi.org/10.29303/jbt.v21i2.2638

Yusro, F., Mariani, Y., Wardenaar, E., \& Yanieta Arbiastutie. (2020). Database Tumbuhan Obat Tradisional Kalimantan Barat (H. A. Oramahi (ed.)). CV Mitra Natawana. Yogyakarta 